\title{
Fetomaternal outcome of thyroid disorder in pregnancy
}

\author{
Rohan Dineshbhai Patel*, Kruti J. Deliwala, Parul T. Shah, Rajani K. Singh
}

Department of Obstetrics and Gynecology, V.S. General Hospital, Ellisbridge, Ahmedabad, Gujarat, India

Received: 14 September 2016

Revised: 15 October 2016

Accepted: 18 October 2016

\section{*Correspondence:}

Dr. Rohan Dineshbhai Patel,

E-mail: rohanpatel4894@gmail.com

Copyright: () the author(s), publisher and licensee Medip Academy. This is an open-access article distributed under the terms of the Creative Commons Attribution Non-Commercial License, which permits unrestricted non-commercial use, distribution, and reproduction in any medium, provided the original work is properly cited.

\section{ABSTRACT}

Background: Thyroid disorders are the commonest endocrine disorders affecting women of reproductive age group and hence constitute the commonest endocrine disorder in pregnancy. It has been recognized that maternal thyroid hormone in excess or less can influence the outcome for mother and fetus at all stages of pregnancy as well as interfere with ovulation and fertility. Thyroid dysfunction is often overlooked in pregnant women because of the nonspecific symptoms and the hyper metabolic state of pregnancy. Hence thyroid function test becomes essential to know the thyroid status in pregnancy and also to detect the subclinical disease. The aim is to study the fetomaternal outcome of pregnant women with thyroid disorders.

Methods: This study is an observational study carried on 500 women coming for antenatal check-up in Tertiary Care Hospital in Ahmedabad from January 2015-December 2015. All women who were included in this study were followed from 18-24 weeks of pregnancy up to delivery.

Results: It was observed that the maximum numbers of patients were in 21-25 years (49\%) age group. Euthyroid $(86 \%)$, hyperthyroid $(01 \%)$, subclinical hyperthyroid $(02 \%)$, hypothyroid $(03 \%)$, and subclinical hypothyroid $(08 \%)$ cases were detected. Neonatal jaundice developed in babies of all hyperthyroid patients, $50 \%$ of patients with Subclinical hyperthyroidism, 53\% of patients with Hypothyroidism, $60 \%$ of patients with Subclinical Hypothyroidism and $11 \%$ of patients with Euthyroid.

Conclusions: TSH is the hallmark in detection of thyroid state of pregnant mother, so TSH should be included in the list of routine investigations done in all antenatal women in second trimester. If TSH values are abnormal then FT3 and FT4 levels need to be checked. Trimester specific reference intervals are of utmost importance by which clinicians can reliably evaluate thyroid function and monitor thyroxine replacement therapy in pregnant women.

Keywords: Feto-maternal outcome, Thyroid disease in pregnancy

\section{INTRODUCTION}

Thyroid disorders are the commonest endocrine disorders affecting women of reproductive age group and hence constitute the commonest endocrine disorder in pregnancy. It has long been recognized that abnormal maternal thyroid hormone can influence the outcome for mother and fetus at all stages of pregnancy as well as interfere with ovulation and fertility. ${ }^{1,2}$

Due to changes in the concentrations of thyroxine binding globulin (TBG), TSH, free $\mathrm{T}_{3}$, free $\mathrm{T}_{4}$, total $\mathrm{T}_{4}$ and $\mathrm{T}_{3}$ during the first trimester of pregnancy it is better to measure $\mathrm{TSH}$, free $\mathrm{T}_{3}$ and free $\mathrm{T}_{4}$ after 18 weeks as the effect of HCG on TSH and free $\mathrm{T}_{4}$ level is minimal as HCG plateaus at $18-20$ weeks. $^{3}$

Relative changes in maternal thyroid associated analytes across pregnancy (Williams $24^{\text {th }}$ Ed.)

Maternal hypothyroidism is the most common disorder of thyroid gland in pregnancy and has been associated with miscarriages, fetal loss, preeclampsia, preterm delivery, placental abruption, low birth weight, fetal distress and reduced intellectual function of the offspring. These adverse outcomes have been associated with both overt 
hypothyroidism found in about $0.2 \%$ of pregnancies as well as subclinical hypothyroidism found in about $2.3 \%$ of pregnancies. ${ }^{4}$ Subclinical hyperthyroidism is found in $0.4 \%$ of pregnancies. ${ }^{5}$
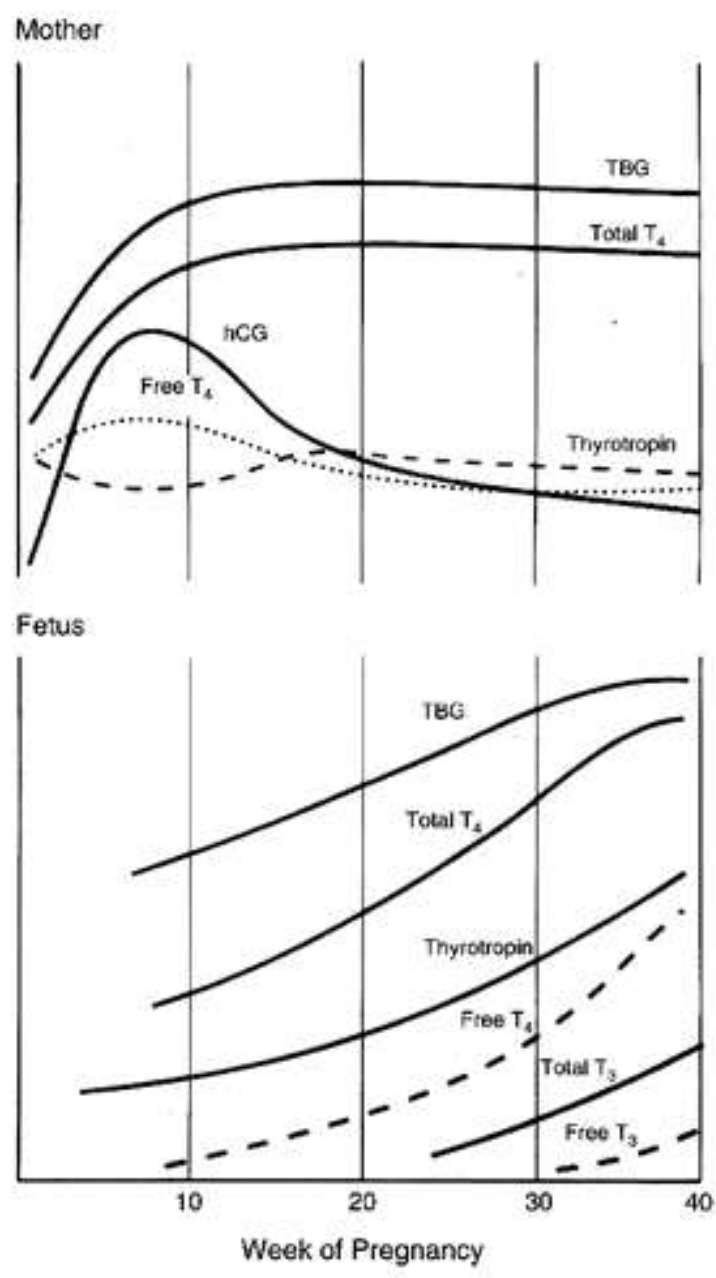

Figure 1: Physiological adaptation in pregnancy.

Maternal and fetal complications of hyperthyroidism include congestive heart failure, thyroid storm, hyperemesis gravidarum, preeclampsia, preterm delivery, fetal growth restriction, still birth, fetal and neonatal thyrotoxicosis. ${ }^{6}$

Thyroid dysfunction is often overlooked in pregnant women because of the nonspecific symptoms and the hyper metabolic state of pregnancy. ${ }^{7}$ Hence thyroid function test becomes essential to know the thyroid status in pregnancy and also to detect the subclinical disease.

\section{METHODS}

This is an observational study carried out in a Tertiary Care Hospital in Ahmedabad and its catchment areas on 500 Antenatal patients between 18-24 weeks of gestation undergoing Antenatal Care follow up.

\section{Data collection}

Inclusion criteria

All pregnant women between 18-24 weeks of pregnancy.

\section{Exclusion criteria}

Multi-fetal gestation known chronic disorder like diabetes and hypertension previous bad obstetric history.

The present study was conducted on 500 antenatal women after obtaining informed consent selected from Tertiary Care Hospital in Ahmedabad. These women were followed from 18-24 weeks up to term. A detailed history was taken regarding the symptoms and sign of thyroid disorders which included menstrual history, obstetric history, past history, past medical history, family history and personal history. A through general physical examination in which Pulse, BP, Temperature, Respiratory rate was noted followed by CVS, CNS, RS, Local thyroid examination. Per abdomen and per vaginal examination was also done. Patient's blood samples were sent for TSH, $\mathrm{FT}_{3}, \mathrm{FT}_{4}$ levels.

American Thyroid Association 2011 recommended trimester-specific reference ranges for TSH are: ${ }^{8}$

- First trimester, 0.1-2.5 $\mu \mathrm{U} / \mathrm{mL}$

- Second trimester, 0.2-3.0 $\mu \mathrm{U} / \mathrm{mL}$

- Third trimester, 0.3-3.0 $\mu \mathrm{U} / \mathrm{mL}$

According to Marwaha et al, the reference intervals for $\mathrm{FT}_{3}, \mathrm{FT}_{4}$ and TSH determined for each trimester of pregnancy in Indian population is higher compared to international cut-offs and recommended for evaluation of thyroid status of pregnant Indian women. ${ }^{9}$

Table 1: Thyroid analytes reference range for Indian women by Marwaha et al.

\begin{tabular}{|llll|}
\hline \multicolumn{1}{|l}{$\begin{array}{l}\text { Marwaha } \\
\text { et al }\end{array}$} & \multicolumn{2}{c|}{ Trimester } \\
\hline & First & Second & Third \\
\hline $\mathrm{FT}_{3}(\mathrm{pmol} / \mathrm{L})$ & $1.92-5.86$ & $3.2-5.73$ & $3.3-5.18$ \\
\hline $\mathrm{FT}_{4}(\mathrm{pmol} / \mathrm{L})$ & $12-19.45$ & $9.48-19.58$ & $11.32-17.70$ \\
\hline $\mathrm{TSH}(\mu \mathrm{U} / \mathrm{ml})$ & $0.6-5.0$ & $0.44-5.78$ & $0.74-5.70$ \\
\hline
\end{tabular}

So in this study following second trimester reference ranges of $\mathrm{FT}_{3}, \mathrm{FT}_{4}$ and TSH are taken.

TSH- 0.44-5.78 $\mu \mathrm{U} / \mathrm{mL}, \mathrm{FT}_{3^{-}}$3.2-5.73 $\mathrm{pmol} / \mathrm{L}, \mathrm{FT}_{4^{-}}$ 9.48-19.58 $\mathrm{pmol} / \mathrm{L}$

(FT3, FT4 and serum TSH were done by chemilumeniscence immunoassay method.) 


\section{Overt hypothyroidism}

This includes women with a TSH concentration above the trimester-specific reference interval $(>5.78 \mu \mathrm{U} / \mathrm{ml})$ with a decreased $\mathrm{FT}_{4}(<9.48 \mathrm{pmol} / \mathrm{L})$ and $\mathrm{FT}_{3}(<3.2 \mathrm{pmol} / \mathrm{L})$, and all women with a TSH concentration $>10.0(\mu \mathrm{U} / \mathrm{ml})$ irrespective of the level of $\mathrm{FT}_{4}$.

\section{Subclinical hypothyroidism}

It is defined as a serum TSH between 5.78 and 10.0 $(\mu \mathrm{U} / \mathrm{ml})$ with normal $\mathrm{FT}_{4}$ and $\mathrm{FT}_{3}$ concentration.

\section{Overt Hyperthyroidism}

It is defined when TSH is low $(<0.44 \mu \mathrm{U} / \mathrm{ml})$ and $\mathrm{FT}_{4}$ $(>19.58 \mathrm{pmol} / \mathrm{L})$ or $\mathrm{FT}_{3}(>5.73 \mathrm{pmol} / \mathrm{L})$ is high.

\section{Subclinical hyperthyroidism}

It occurs when $\mathrm{FT}_{4}(>19.58 \mathrm{pmol} / \mathrm{L})$ or $\mathrm{FT}_{3}(>5.73$ $\mathrm{pmol} / \mathrm{L})$ is high and TSH normal $(0.44-5.78 \mu \mathrm{U} / \mathrm{ml})$.

In overt and subclinical hypothyroidism, thyroxine dosage was titrated to maintain serum $\mathrm{TSH}<5.78 \mu \mathrm{U} / \mathrm{ml}$ in second trimester and $<5.70 \mu \mathrm{U} / \mathrm{ml}$ in third trimester. In overt hyperthyroidism, PTU (propylthiouracil) was given to the patient. Every 6-8 weekly TSH levels were estimated and the dose of drug adjusted accordingly. At the end, the obstetrical and perinatal outcome of pregnancy was noted.

\section{RESULTS}

Table 2: Age distribution of all 500 cases.

\begin{tabular}{|lll|}
\hline Age group (years) & $\mathbf{N}=500$ & Percentage \\
\hline $18-20$ & 60 & $12 \%$ \\
\hline $21-25$ & 245 & $49 \%$ \\
\hline $26-30$ & 175 & $35 \%$ \\
\hline $31-35$ & 20 & $04 \%$ \\
\hline
\end{tabular}

Maximum numbers of patients were in 21-25 years (49\%) age group.

Table 3: Overall thyroid status of all 500 cases.

\begin{tabular}{|l|l|l|}
\hline & $\mathrm{N}=500$ & $\%$ \\
\hline Euthyroid & 430 & $86 \%$ \\
\hline Subclinical Hypothyroid & 40 & $08 \%$ \\
\hline Hypothyroid & 15 & $03 \%$ \\
\hline Subclinical Hyperthyroid & 10 & $02 \%$ \\
\hline Hyperthyroid & 05 & $01 \%$ \\
\hline
\end{tabular}

It was observed that the maximum numbers of patients were in 21-25 years (49\%) age group. Euthyroid (86\%), hyperthyroid $(01 \%)$, subclinical hyperthyroid $(02 \%)$, hypothyroid $(03 \%)$, and subclinical hypothyroid $(08 \%)$ cases were detected. Neonatal jaundice developed in babies of all hyperthyroid patients, $50 \%$ of patients with Subclinical hyperthyroidism, 53\% of patients with hypothyroidism, $60 \%$ of patients with subclinical hypothyroidism and $11 \%$ of patients with Euthyroid.

Table 4: TSH specific reference ranges and maternal and fetal outcome.

\begin{tabular}{|c|c|c|c|c|c|c|c|c|c|c|c|c|}
\hline \multirow[b]{2}{*}{ Thyroid status } & \multirow[b]{2}{*}{$\begin{array}{l}\text { No. } \\
\text { of } \\
\text { cases } \\
(500)\end{array}$} & \multicolumn{2}{|c|}{ >37 Weeks } & \multicolumn{2}{|c|}{ <37 Weeks } & \multirow{2}{*}{ 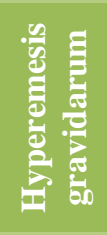 } & \multirow{2}{*}{ 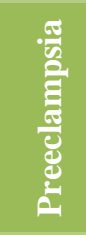 } & \multirow[b]{2}{*}{ 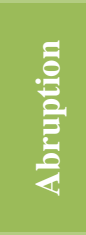 } & \multirow[b]{2}{*}{$\frac{0}{2}$} & \multirow[b]{2}{*}{ 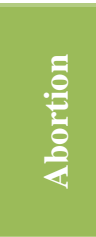 } & \multirow[b]{2}{*}{ שै } & \multirow[b]{2}{*}{ 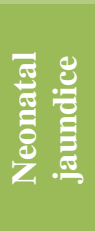 } \\
\hline & & $\underset{Z}{Z}$ & 记 & $\dot{8}$ & $\sum_{1}^{\infty}$ & & & & & & & \\
\hline Euthyroid (\%) & $\begin{array}{l}430 \\
(86)\end{array}$ & $\begin{array}{l}174 \\
(40)\end{array}$ & $\begin{array}{l}73 \\
(17)\end{array}$ & $\begin{array}{l}118 \\
(27)\end{array}$ & $\begin{array}{l}49 \\
(11)\end{array}$ & $\begin{array}{l}15 \\
(03)\end{array}$ & $\begin{array}{l}38 \\
(09)\end{array}$ & $\begin{array}{l}10 \\
(02)\end{array}$ & $\begin{array}{l}04 \\
(01)\end{array}$ & $\begin{array}{l}12 \\
(03)\end{array}$ & $\begin{array}{l}10 \\
(02)\end{array}$ & $\begin{array}{l}50 \\
(11)\end{array}$ \\
\hline $\begin{array}{l}\text { Subclinical } \\
\text { hypothyroid (\%) }\end{array}$ & $\begin{array}{l}40 \\
(08)\end{array}$ & $\begin{array}{l}18 \\
(45)\end{array}$ & $\begin{array}{l}06 \\
(15)\end{array}$ & $\begin{array}{l}08 \\
(20)\end{array}$ & $\begin{array}{l}04 \\
(10)\end{array}$ & $\begin{array}{l}00 \\
(00)\end{array}$ & $\begin{array}{l}04 \\
(10)\end{array}$ & $\begin{array}{l}02 \\
(05)\end{array}$ & $\begin{array}{l}01 \\
(2.5)\end{array}$ & $\begin{array}{l}03 \\
(7.5)\end{array}$ & $\begin{array}{l}02 \\
(05)\end{array}$ & $\begin{array}{l}24 \\
(60)\end{array}$ \\
\hline $\begin{array}{l}\text { Overt hypothyroid } \\
(\%)\end{array}$ & $\begin{array}{l}15 \\
(03)\end{array}$ & $\begin{array}{l}02 \\
(13)\end{array}$ & $\begin{array}{l}00 \\
(00)\end{array}$ & $\begin{array}{l}05 \\
(33)\end{array}$ & $\begin{array}{l}03 \\
(20)\end{array}$ & $\begin{array}{l}00 \\
(00)\end{array}$ & $\begin{array}{l}03 \\
(13)\end{array}$ & $\begin{array}{l}01 \\
(07)\end{array}$ & $\begin{array}{l}03 \\
(20)\end{array}$ & $\begin{array}{l}02 \\
(13)\end{array}$ & $\begin{array}{l}02 \\
(13)\end{array}$ & $\begin{array}{l}08 \\
(53)\end{array}$ \\
\hline $\begin{array}{l}\text { Subclinical } \\
\text { hyperthyroid (\%) }\end{array}$ & $\begin{array}{l}10 \\
(02)\end{array}$ & $\begin{array}{l}07 \\
(70)\end{array}$ & $\begin{array}{l}03 \\
(30)\end{array}$ & $\begin{array}{l}00 \\
(00)\end{array}$ & $\begin{array}{l}00 \\
(00)\end{array}$ & $\begin{array}{l}01 \\
(10)\end{array}$ & $\begin{array}{l}01 \\
(10)\end{array}$ & $\begin{array}{l}00 \\
(00)\end{array}$ & $\begin{array}{l}00 \\
(00)\end{array}$ & $\begin{array}{l}00 \\
(00)\end{array}$ & $\begin{array}{l}00 \\
(00)\end{array}$ & $\begin{array}{l}05 \\
(50)\end{array}$ \\
\hline Hyperthyroid (\%) & $\begin{array}{l}05 \\
(01)\end{array}$ & $\begin{array}{l}04 \\
(80)\end{array}$ & $\begin{array}{l}00 \\
(00)\end{array}$ & $\begin{array}{l}00 \\
(00)\end{array}$ & $\begin{array}{l}01 \\
(20)\end{array}$ & $\begin{array}{l}04 \\
(80)\end{array}$ & $\begin{array}{l}00 \\
(00)\end{array}$ & $\begin{array}{l}00 \\
(00)\end{array}$ & $\begin{array}{l}00 \\
(00)\end{array}$ & $\begin{array}{l}00 \\
(00)\end{array}$ & $\begin{array}{l}00 \\
(00)\end{array}$ & $\begin{array}{l}05 \\
(100)\end{array}$ \\
\hline
\end{tabular}

\section{DISCUSSION}

On the basis of the results of this study, combined with those reported in the literature, some recommendations can be drawn.
Overt or inadequately treated hypothyroidism is a risk factor of miscarriage and possibly preterm birth and fetal death (Abalovich et al, Allan et al). ${ }^{4,10}$ This study showed that in patients having overt hypothyroidism $20 \%$ had IUD, $13 \%$ developed preeclampsia, 53\% presented with preterm labour and $07 \%$ had abruption where as those 
with overt hyperthyroidism-80\% had hyperemesis gravidarum.

Thyroid function tests should be performed in all patients as a routine screening procedure as there is very high prevalence of thyroid disorders in Indian female. Adverse effects of thyroid disorders on pregnancy can be avoided if diagnosed early and the effects on maternal and neonatal morbidity and mortality can be reduced. These findings indicate that adequate treatment of those with known hypothyroidism and reassessement of those at risk of progressing to overt hypothyroidism during pregnancy is to be recommended- preferably before pregnancy. It is recommended that those with overt hyperthyroidism, as defined by the new trimester-specific reference intervals, are treated and closely monitored, as the need for antithyroid therapy typically decreases as pregnancy progresses.

\section{CONCLUSION}

By gestational age specific reference intervals clinicians can reliably evaluate thyroid function and monitor thyroxine replacement therapy in pregnant women. TSH is the hallmark in detection of hypothyroid as well hyperthyroid so TSH should be included in the list of routine investigations done in all antenatal women in first trimester. If TSH values are abnormal then FT3 and FT4 levels need to be checked. Trimester specific reference intervals are of utmost importance by which clinicians can reliably evaluate thyroid function and monitor thyroxine replacement therapy in pregnant women. If available then TPOAb should be tested to rule out autoimmune cause of thyroidism and treated accordingly.

The impact of thyroid disorders is not immediately visible; however, undetected and untreated thyroid disorders during pregnancy adversely impacts the health of both the mother and the infant. At the moment, thyroid dysfunction is detected by a case finding approach rather than universal screening of all pregnant women. Thus, a guideline of universal screening for thyroid disorders is very helpful for early diagnosis and management in such patients and improve maternal and fetal outcome.

\section{ACKNOWLEDGEMENTS}

We hereby would like to thank Dr. ST Malhan, the superintendent of Sheth V. S. General Hospital, Dr. Pankaj R Patel, the dean of Smt N. H. L. Municipal Medical College to allow us to publish this paper.
Funding: No funding sources

Conflict of interest: None declared

Ethical approval: The study was approved by the Institutional Ethics Committee

\section{REFERENCES}

1. Casey BM, Leveno KJ. Thyroid disease in pregnancy. Obstet Gynecol. 2006;108:1283-92.

2. Casey BM, Dashe JS, Wells CE, McIntire DD, Byrd EW, Leveno KJ, et al. Subclinical Hypothyroidism and pregnancy outcomes. Obstet Gynecol. 2005;105:239-45.

3. Cunningham FG, Lenovo KJ, Bloom SL, Spong CY, Dashe JS, Hoffman BL, et al. 24 ${ }^{\text {th }}$ edition; 2014:69.

4. Abalovich M, Gutierrex S, Alcaraz G, Maccallini G, Garcia A, Levalle O. Overt and subclinical hypothyroidism complicating pregnancy. Thyroid. 2002;12:63-8.

5. Mestman JH. Hyperthyroidism in pregnancy. Endocrinol Metab Clin North Am. 1998;27(1):12749.

6. Hadley ME, Levine JE. Thyroid hormones. In: Endocrinology. Upper Saddle River, NJ, Pearson Prentice Hall; 2007:293-314.

7. Välimäki M, Schalin-Jäntti C, Kilpirauhanen In: M. Välimäki, T. Sane and L. Dunkel (eds) Endokrinologia. Helsinki, Kustannus Oy Duodecim; 2009:174-230.

8. Stagnaro-Green, Abalovich. Guidelines of the American Throid Association for the Diagnosis and Management of Thyroid Disease during Pregnancy and Postpartum - Thyroid. 2011;21(10):1081-125.

9. Marwaha R, Chopra S, Gopalakrishnan S, Sharma B, Kanwar R, Sastry A, et al. Establishment of reference range for thyroid hormones in normal pregnant Indian women. BJOG: An Int J of Obs and Gyn. 2008;115:602-6.

10. Allan WC, Haddow JE, Palomaki GE, Williams JR, Mitchell ML, Hermos RJ, et al. Maternal thyroid deficiency and pregnancy complications: implications for population screening. Klein J Med Screen. 2000;7:127-30.

Cite this article as: Patel RD, Deliwala KJ, Shah PT, Singh RK. Fetomaternal outcome of thyroid disorder in pregnancy. Int $\mathrm{J}$ Reprod Contracept Obstet Gynecol 2016;5:4466-9. 